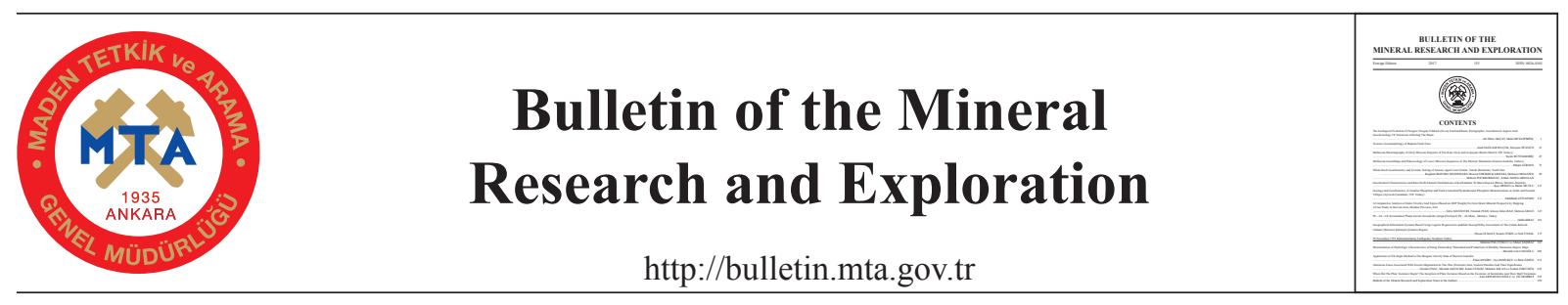

\title{
WHEN DID THE PLATE TECTONICS BEGIN? THE INCEPTION OF PLATE TECTONICS BASED ON THE EXISTENCE OF KOMATIITES AND THEIR MgO VARIATIONS
}

\author{
Anıl ARDAHANLIOĞLU ${ }^{a^{*}}$ and Efe DEMİRCI ${ }^{b}$ \\ ${ }^{a}$ Ankara University, Dept. of Geological Eng., Tectonics Research Group, Gölbaşl, Ankara. orcid.org/0000-0001-9309-3872 \\ ${ }^{b}$ Ankara University, Dept. of Geological Eng., Tectonics Research Group, Gölbaşl, Ankara. orcid.org/0000-0002-6290-1731
}

Short Note

Keywords:

Crust, Plate Tectonic, Continental Crust, Earth, Komatiite.
Received Date: 03.03.2017 Accepted Date: 24.04.2017

\begin{abstract}
The geoscientists have always wondered what evolutionary processes the Early Earth went through until it reached today. The beginning of the plate tectonics poses another matter of debate in these processes. Yet, the debates on when the plate tectonics began have not been resolved. In this sense, especially the lack of records regarding the period of time before the Cambrian Era is considered the biggest obstacle against resolution of these debates. The geoscientists have befitted from various methods to come up with different proposals about the beginning of the plate tectonics. The most notable rock type among the ones produced by the mantle is the komatiites. While the oldest datable komatiite is 3.82 $\mathrm{Ga}$; the youngest is $0.086 \mathrm{Ga}$. With the high content of magnesium they contain, their special texture and the geological setting, the komatiites are not similar to any other rock groups which can currently be examined. Though they were produced in different geological times, no up to date forms of these rocks have been observed. Given the formation conditions of komatiites, recorded time intervals and the content of magnesium they contain, they might indicate when the plate tectonics began.
\end{abstract}

\section{Introduction}

In order to understand the Earth's history it is of a great importance to know when and how the plate tectonics began. Korenaga (2013) summarized certain studies on the beginning of plate tectonics, proposing that the plate tectonics might have begun between Hadean $(>4.2 \mathrm{Ga})$ and Mesoproterozoic $(\sim 1 \mathrm{Ga})$ (Figure 1). The differences observed in the suggested age ranges is due to the fact that each researcher use different probable evidences in order to make proposals about the beginning of plate tectonics. New studies conducted in this field lead to new probable evidence. Examining the studies which have been conducted until today, it is possible to say that to resolve the debates on the beginning of plate tectonics is not an easy task.

Gerya et al. (2015) showed that the plate tectonics involve the independent movement of lithospheric plates and therefore understanding how plate tectonics began requires an understanding of how the first subduction zone formed. Further, Gerya et al. (2015) provided a detailed examination of various proposals about the beginning of plate tectonics and their relationship with the mantle plumes.

Examining the previous studies on the beginning of plate tectonics (Komiya et al., 1999; Stern, 2005; Brown, 2006; Cawood et al., 2006; Hopkins et al., 2008; Shirey et al., 2008; Condie and Kröner, 2008; Harrison, 2009; Korenaga, 2013; Blichert-Toft et al., 2015; Nutman et al., 2015; Stern et al., 2017) it can be seen that the majority of these works comply with the indicators of plate tectonics proposed by Condie and Kröner (2008). Within the scope of this paper, it is proposed that there might be a link between the age interval of komatiites (Condie et al. 2016) and the beginning of plate tectonics.

\section{Komatiites, a Proposed Indicator of the Beginning of the Plate Tectonics}

Komatiites were first recognised in the Barberton greenstone belt (South Africa) by Viljoen and Viljoen (1969). The simple definition of komatiite is an 


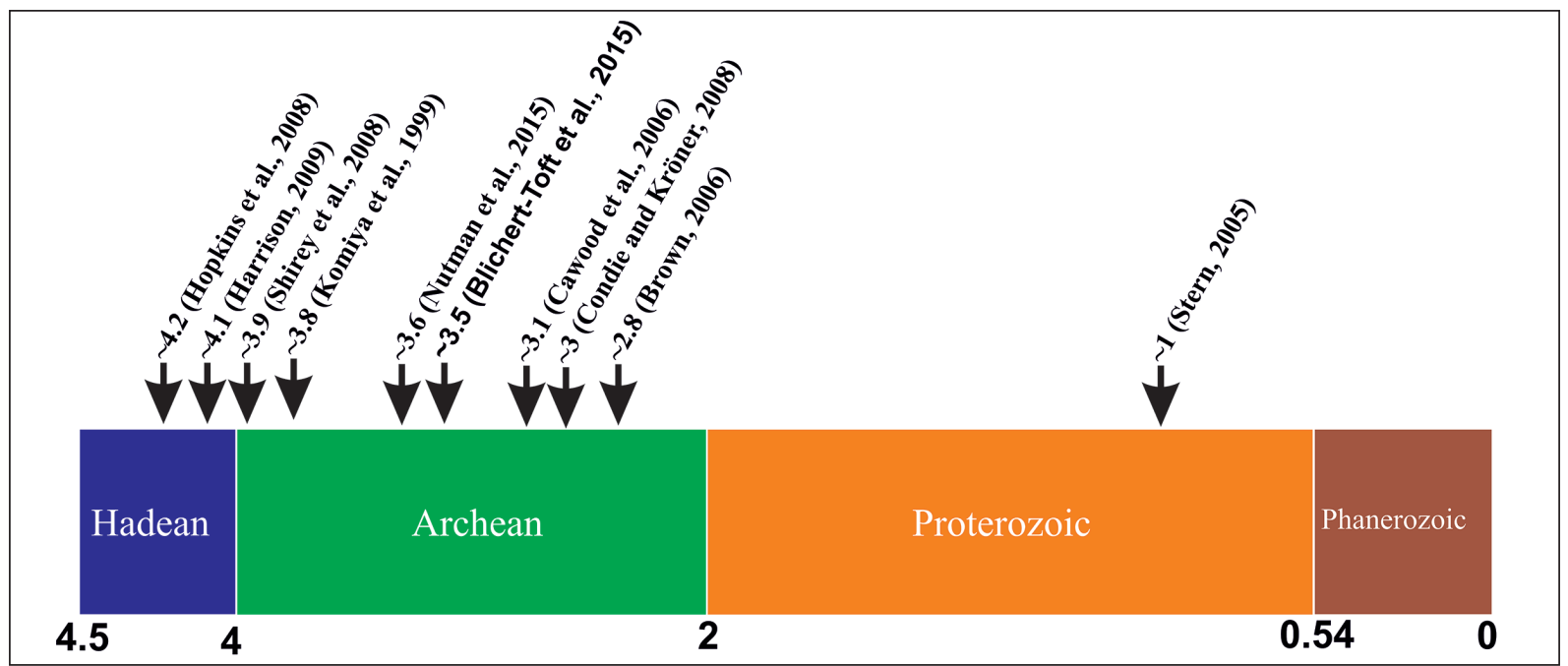

Figure 1- Proposals for the beginning age of plate tectonics (after Korenaga, 2013). The ages are billion years.

ultramafic volcanic rock (Arndt and Nisbet 1982). According to IUGS rock classification (Le Bas and Streckeisen, 1991; Le Maitre et al., 2002) komatiites contain more than $18 \mathrm{wt} . \% \mathrm{MgO}$ and less than 1 wt. $\% \mathrm{TiO}_{2}$ Though it is difficult to prove, komatiites crystallize from liquids that contained more than about $18 \% \mathrm{MgO}$ (Arndt and Lesher, 2004). Condie et al. (2016) limited the definition of Basalt to $\mathrm{MgO}$ of 7-17 wt. $\%$ and $\mathrm{SiO}_{2}$ of 45-55 wt.\%, whilst Komatiites are restricted to $\mathrm{MgO}$ of $17-35$ wt. $\%$. Thus, the $\mathrm{MgO}$ of wt.\% value is a distinguishing feature for Komatiites (Le Bas and Streckeisen, 1991; Kerr and Arndt, 2001;
Le Maitre et al., 2002; Arndt and Lesher, 2004; Condie el al., 2016).

The oldest datable is $3.8 \mathrm{Ga}$ (Nuvvuagittuq greenstone belt; Condie et al., 2016), with the youngest being $0.86 \mathrm{Ga}$ (Gorgona Island, Colombia; Revillon et al., 2000; Kamenetsky et al., 2010). Komatiites are rarely found today. Condie et al. (2016) (Figure 2) summarized the previous studies on komatiites.

When the $\mathrm{MgO}$ of wt.\% averages and age values of the komatiites are examined, it is seen that there is a

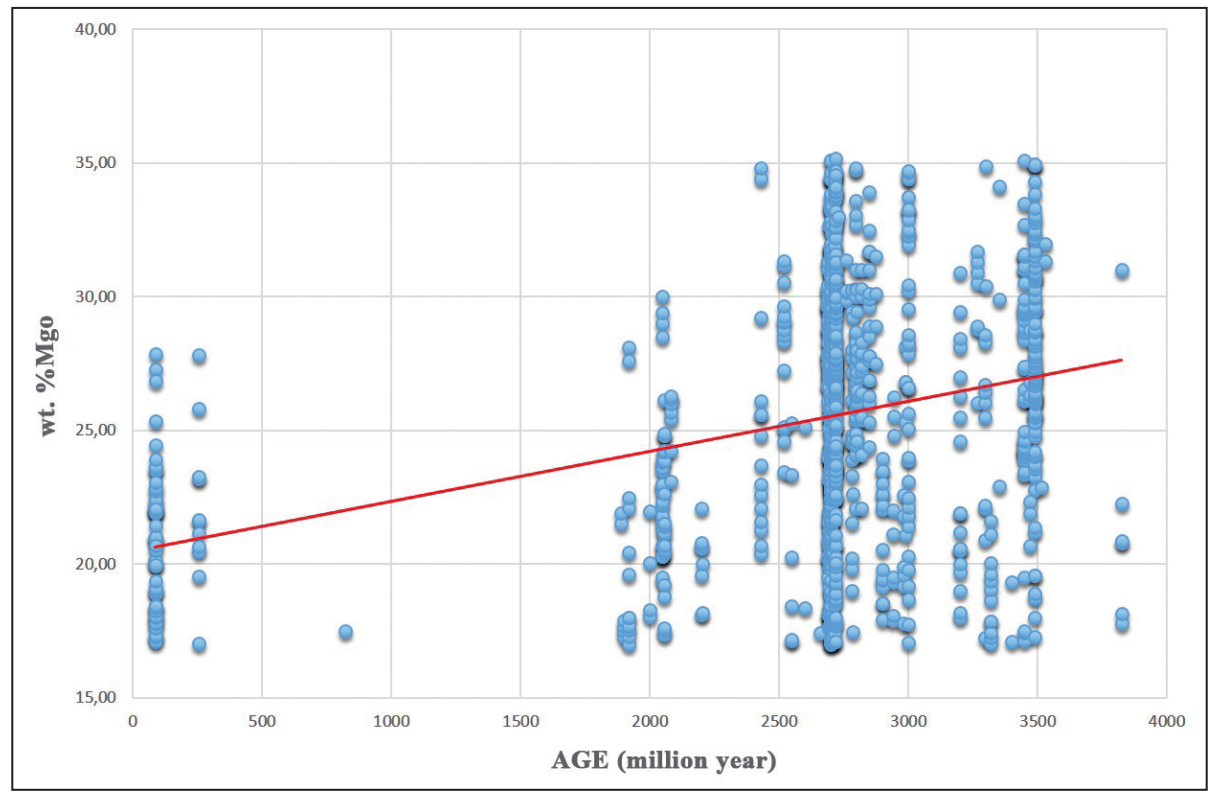

Figure 2- The graphic about age and $\mathrm{w} \% \mathrm{MgO}$ values given for komatiites. The red line represents the decreasing trend of $\mathrm{w} \% \mathrm{MgO}$ depending on age (after Condie et al., 2016). 
significant decrease in these values from the oldest to the young ones (Figure 2).

Parman et al. (2001) describe in detail the geological settings of the chemical composition and formation mechanisms between basaltic komatiites and boninites. In addition, based upon their geochemical similarity, Parman et al. (2001) propose that the $3.5 \mathrm{Ga}$ Barberton basaltic komatiites are the Archean equivalents of modern boninites, showing a possible relationship between basaltic komatiites and boninites. The Gorgona and Belingwe komatiites were formed by the melting of pyrolite; but it is not possible to explain some of the komatiitic geochemical features within the context of pyrolyte melting process (Walter, 1998). Parman et al. (2001) proposed that the relatively low pressures and temperatures required to produce Barberton komatiitic magmas by hydrous melting are consistent with formation in a subduction zone.

\section{Relation Between Komatiites and Plate Tectonics}

Given the proposed formation temperatures of komatiites by Parman et al. (2001), the Earth's primitive crust should be of a komatiitic character (Santosh et al., 2017). Therefore, the mantle forming the primitive crust must also be komatiitic. Next, the primitive crust and mantle could have formed the primitive continental nuclei by independent systems of plate tectonics (non-subduction systems), as proposed by Bédard (2006) and Zhang et al. (2013). Gerya et al. (2015) proposed that plume-induced subduction initiation started plate tectonic processes in the transition from stagnant lid convection. In this sense, the plumes formed in this period, when the first movements of the plate tectonics started should also be komatiitic (Figure 3).

According to IUGS rock classification (Le Bas and Streckeisen, 1991; Le Maitre et al., 2002), a significant decrease is observed in the amount of wt.\% $\mathrm{MgO}$ (on avarage $10 \%)$ in the transition from komatiites $(\mathrm{MgO}$ $>18$ wt. $\left.\%, \mathrm{TiO}_{2}<1 \%\right)$ to boninites $\left(\mathrm{MgO}>8 \%, \mathrm{TiO}_{2}<\right.$ $0.5 \%$ ). It is also possible to see this theoretical case in the figure about komatiites (Figure 2). This significant decrease can be explained with the increase degree in partial melting processes and the formation of $\mathrm{SiO}_{2}$ rich melts as a result of subduction. Condie et al. (2016) examined the reason for the reduction in $\mathrm{MgO}$ of wt. $\%$ and observed that the primary komatiitic mantle composition what is possible to remove the result that the komatiites having a lower wt.\% $\mathrm{MgO}$ content are produced with developing subduction zones diluted over time (Figure 3). In this sense, the komatiites which have more $\mathrm{SiO}_{2}$ and less $\mathrm{MgO}$, must have turned into to juvenile basaltic komatiites and later boninites by increasing $\mathrm{SiO}_{2}$ amounts over time.

Transition from komatiites to basaltic komatiites and boninites observed in relation to the beginning of plate tectonics is also supported by Parman et al. (2001).

According to the current data, examining all these proposals and considering the significant decrease in the $\mathrm{wt} \%$. MgO of komatiites, the starting age of the plate tectonics and subduction should be $3.8 \mathrm{Ga}$ due.

\section{Conclusions and Recommendations}

No consensus has been reached in the literature on the formation of komatiites. There are studies to suggest that based on subductions (Parman et. al., 2001, Parman et. al., 2004) and based on mantle plumes (Arndt et. al., 1998, 2008; Herzberg et. al., 2007) of komatiites. Parman et al. (2001) suggested that the formation of Barberton komaiitic magmas in the subduction zones is consistent. Researchers who prefer based on mantle plumes, said that the temperature and depth conditions required for the formation of komatiites could not be met in subduction zones. However, according to Korenega (2013) for Archean, considering the different ambient conditions of this period, the hotter Archean mantle may have provided the adequate temperature conditions for the komatiites to form in subduction zones.

The decrease in $\mathrm{MgO}$ wt.\% in the komatiites (Figure 2) should be examined to identify if they can be count as a proxy of the beginning of the plate tectonics.

Plate tectonics, which are proposed to have started at least $3.8 \mathrm{Ga}$, should have continued by accelerating to evolve over time until $1.9 \mathrm{Ga}$. As of $1.9 \mathrm{Ga}$, the system, was accelerated by the development of all the force mechanisms that currently operate the plate movements, has stopped the production of komatiites.

While Archean komatiites formed at high temperature, Cretaceous komatiites were formed at lower temperatures (Walter, 1998). Due to changed ambient conditions (Korenaga, 2013) and significant 


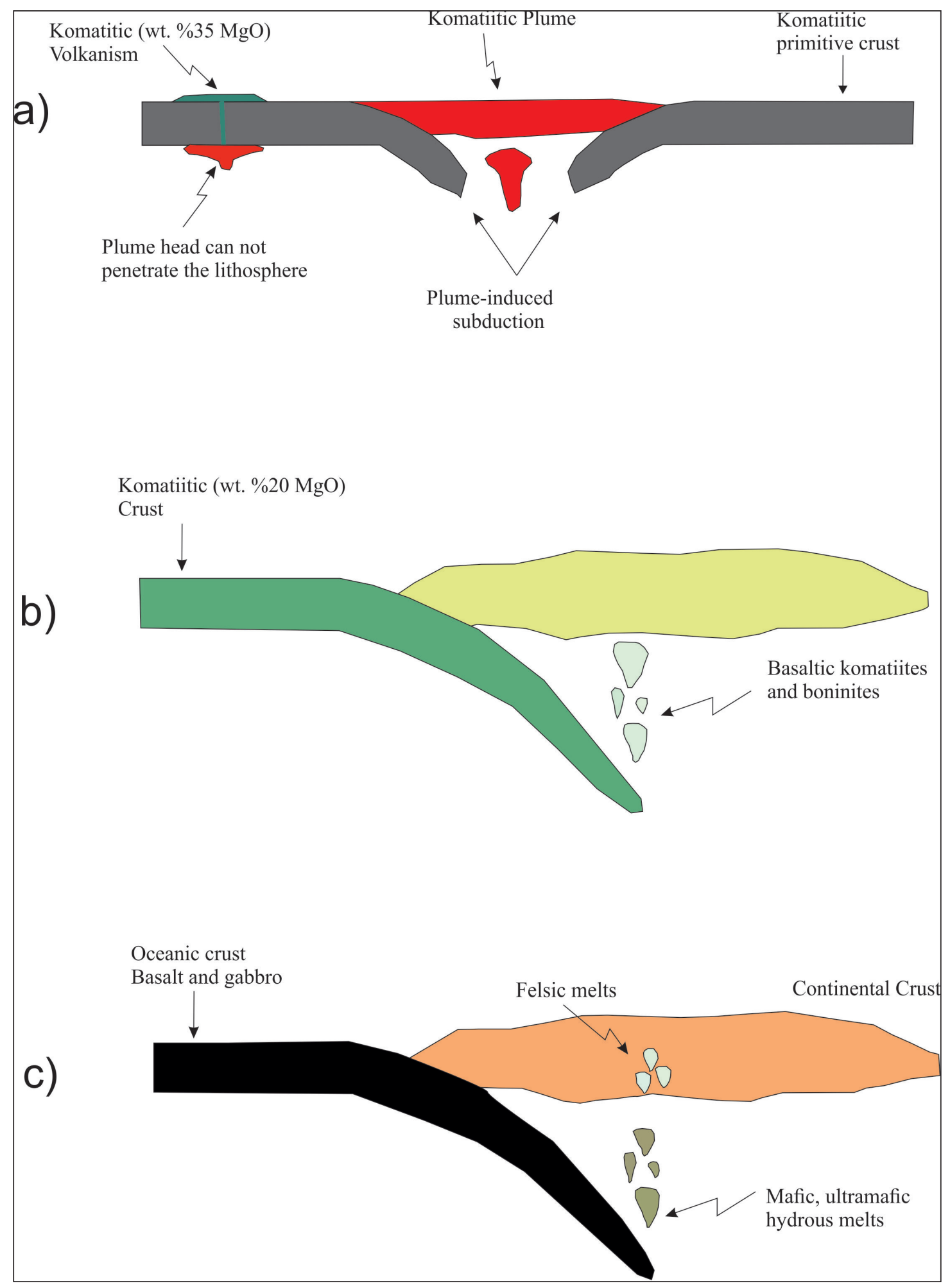

Figure 3- Schematic representation of the relationship between komatiites and plate tectonics (Unscaled). Respectively a-b-c are geologically ordered from older to younger. a) Gerya et al. (2015) initiates the first subdubction events that result in the penetrate the lithosphere. b) Formation of solutions with less $\mathrm{w} \% \mathrm{MgO}$ content than the already existing komatiitic crust, which is partially melted by subduction events. c) Formation of felsic melts by partial melting from the currently observed oceanic crust. The proposed plate movements, which began about 3.8 billion years ago, have resulted in the production of mantle material with a lower $\mathrm{w} \% \mathrm{MgO}$ content, depending on the time. In other words, it reduces the content of $\mathrm{w} \% \mathrm{MgO}$ that the mantle composition possesses, thus laying the groundwork for diluting the mantle. 
differences in $\mathrm{MgO}$ contents it would be more accurate to evaluate the role of komatiites formed in two different times in separate systems.

The details and the development of the working mechanisms of the first plate movements, which are considered to be slower than today (Bradley, 2008; Korenaga, 2013), are not fully known.

It is should be investigated whether all of the mechanisms that currently operate the plate movements were present in the Paleoarchean.

While investigating the history of Earth (especially before $2 \mathrm{Ga}$ ) within the principle of actualism, considering the processes that occurred on Earth's crust which cannot be subjected to a present-day analogy, the idea of change should not be ignored.

\section{Acknowledgements}

We would like to thank our valuable Professors Gürol Seyitoğlu and Korhan Esat for providing us full support and contribution to our work. We are also immensely grateful to Aral İ. Okay, Halim Mutlu and Ali Polat for their contribution to this paper with their valuable critics. The manuscript is benefited critical reviews of Timur Ustaömer, Franco Pirajno and other anonymous referee for which we are grateful.

\section{References}

Arndt, N. T., Nisbet, E. G. 1982. What is a komatiite?, in Komatiites, edited by N. T. Arndt and E. G. Nisbet, Allen and Unwin, Concord, Massachusetts 1928

Arndt, N., Ginibre, C., Chauvel, C., Albarède, F., Cheadle, M., Herzberg, C., Jenner, G., Lahaye, Y. 1998. Were komatiites wet? Geology, 26, 739-742.

Arndt, N., Lesher, C.M. 2004. Komatiite. Encyclopedia of Geology. Elsevier, 260-268.

Arndt, N., Lescher, C., Barnes, S. J. 2008. Komatiite. Cambridge University Press, Cambridge.

Bédard, J.H. 2006. A catalytic delamination-driven model for coupled genesis of Archaean crust and subcontinental lithospheric mantle. Geochimica et Cosmochimica Acta 70, 1188-1214, doi:10.1016/j.gca.2005.11.008.

Blichert-Toft, J., Arndt, N.T., Wilson, A., Coetzee, G. 2015. $\mathrm{Hf}$ and $\mathrm{Nd}$ isotope systematics of early Archean komatiites from surface sampling and ICDP drilling in the Barberton Greenstone Belt, South Africa. American Mineralogist 100, 2396-2411.
Bradley D. C. 2008. Passive margins through earth history. Earth-Science Reviews. 91:1-26

Cawood, P.A., Kröner A., Pisarevsky S. 2006. Precambrian plate tectonics: criteria and evidence. Geological Society of America Today 16, 4-11.

Condie, K.C., Kröner A. 2008. When did plate tectonics begin? Evidence from the geologic record. See Condie \& Pease 2008. Geological Society of America Spacial Papers 440, 281-94, doi: 10.1130/2008.2440(14)

Condie, K.C., Aster, C.R., van Hunen, J. 2016. A great thermal divergence in the mantle beginning 2.5 Ga:Geochemical constraints from greenstone basalts and komatiites. Geoscience Frontiers 7, 4, 543-553, doi:10.1016/j.gsf.2016.01.006.

Gerya, T. V., Stern, B.,Baes, M., Sobolev, S. V., Whattam, S. A. 2015. Plate tectonics on the Earth triggered by plume-induced subduction initiation. Nature 527, 221-225, DOI: 10.1038/nature 15752

Harrison, T.M. 2009. The Hadean crust: Evidence from $>4$ Ga zircons. Annual Reviews of Earth and Planetary Sciences, 37, 479-505.

Herzberg, C., Asimow, P., D., Arndt, N., Niu, Y., Lesher, C., M., Fitton, J., G., Cheadle, M., J., Saunders., A., D. 2007. Temperatures in ambient mantle and plumes: constraints from basalts, picrites, and komatiites. Geochemistry, Geophysics, Geosystems, 8, 1-34.

Hopkins M., Harrison T.M., Manning C.E. 2008. Low heat flow inferred from $>4 \mathrm{Gyr}$ zircons suggests Hadean plate boundary interactions. Nature 456, 493-96.

Kerr, A. C., Arndt, N. T. 2001. A note on the IUGS reclassification of the high-Mg and picritic volcanic rocks. Journal of Petrology 42, 11, 2169-2171.

Komiya T., Maruyama S., Masuda T., Nohda S., Hayashi M., Okamoto K., 1999. Plate tectonics at 3.8-3.7 $\mathrm{Ga}$ : field evidence from the Isua accretionary complex, southern West Greenland: Journal of Geology 107, 515-54.

Korenaga, J. 2013. Initiation and evolution of plate tectonics on Earth. Theories and Observations. Annual Review of Earth and Planetary Sciences 41, 117151.

Le Bas, M.J., Streckeisen, A. L. 1991. The IUGS systematics of igneous rocks. Journal of the Geological Society, London 148,825-833.

Le Maitre, R. W. 2002. Igneous Rocks. A Classification And Glossary Of Terms. Recommendations Of 
The International Union Of Geological Sciences Subcommission On The Systematics Of Igneous Rocks, 2nd Ed. Xvi + 236 Pp. Cambridge

Nutman, A.P., Bennett, V.C., Friend, C.R.L. 2015. Proposal for a continent 'Itsaqia' amalgamated at 3.66 $\mathrm{Ga}$ and rifted apart from $3.53 \mathrm{Ga}$ : Initiation of a Wilson Cycle near the start of the rock record. American Journal of Science, 315, 509-536.

Parman, S. W., Grove, S. T., Dann, J. 2001. The production of Barberton komatiites in an Archean subduction zone. Geophysical Research Letters 28, 25132516 .

Parman, S. W., Grove, T. L., Dann, J. C., deWit, M. J. 2004. A subduction origin for komatiites and cratonic lithospheric mantle. South African Journal of Geology, 107, 107-118.

Santosh, M., Arai, T., Maruyama, S. 2017. Hadean Earth and primordial continents: the cradle of prebiotic life. Geoscience Frontiers, 8, 309-327.

Shirey S.B., Kamber B.S., Whitehouse M.J., Mueller P.A., Basu A.R. 2008. A review of the isotopic and trace element evidence for mantle and crustal processes in the Hadean and Archean. implications for the onset of plate tectonic subduction. in Condie, K.C., and Pease, V., eds., When Did Plate
Tectonics Begin on Planet Earth?: Geological Society of America Special Paper 440, p. 1-29, doi: 10.1130/2008.2440(01))

Stern, R.J. 2005. Evidence from ophiolites, blueschists, and ultrahigh-pressure metamorphic terranes that the modern episode of subduction tectonics began in Neoproterozoic time. Geology 33, 557-60

Stern, R. J., Leybourne, M. I., Tsujimori. T. 2017. Kimberlites and the start of plate tectonics. Geology. DOI: $10.1130 / \mathrm{G} 38024.1$

Viljoen, M. J., Viljoen, R. P. 1969. The geology and geochemistry of Lower Ultramafic Unit of the Onverwatch Group and a proposed new class of igneous rocks. In: Upper Manttle Project, Geological Society of South Africa Special Publication 2, 55-85.

Walter, J. M. 1998. Melting of Garnet Peridotite and the Origin of Komatiite and Depleted Lithosphere. Journal of Petrology 39, 1, 29-60.

Zhang, C., Holtz, F., Koepke, J., Wolff, P. E., Ma, C., Bedard, J. 2013. Constraints from experimental melting of amphibolite on the depth of formation of garnetrich restites, and implications for models of Early Archean crustal growth. Precambrian Research 231, 206-217. 